\title{
EFFECT OF WATER MANAGEMENT AND USE OF DRY BIO GAS FERTILIZER ON THE CORIANDER CROP PRODUCTIVITY
}

\author{
Mansour H. Elbakhshwan ${ }^{1}$, Hussien A. Elsoury ${ }^{1}$, \\ Mohamed M. Nabih Khalil ${ }^{1}$ and Hamed M. El-Kony ${ }^{2}$ \\ ABSTRACT
}

Irrigation is a very important factor as well as fertilization, affecting the growth and yield of plants. Coriander plants have several uses in pharmaceutical and food industries; because of its great importance, more investigations for improving the growth and productivity of this plant are still needed. The aim of this research is to study the effect of dry biogas fertilizer (dry digested biomass resulted from biogas digesters) and irrigation water regime conditions on the Coriander crop (Coriandrumsativum L.) production. The experimental work was conducted during November 2016 at Tractors and Farm machinery Testing \& Research Station at Sabahia, Alexandria Governorate, Egypt. Results indicated high significant differences of mean values of the plant growth parameters for all treatments, while the highest significant difference resulted due to the effect of the treatment [irrigation water regime (15) times, depth from surface soil (10) cm and amount of biogas fertilizer (15) $\left.\mathrm{m}^{3} / \mathrm{Fed}\right]$, where the values of plant height $H$, number of branches (NB), number of umbels (NF) and umbels diameter were 90.03 $\mathrm{cm}, 6.60,80.30$ and 4.3 respectively compared with the control treatment. Also the results of physical and chemical analysis of soil after harvesting showed high improvements, where the maximum mean values of total porosity, (T.P\%), hydraulic conductivity $(\mathrm{Kb} \mathrm{Cm} / \mathrm{h})$, total nitrogen (T.N\%) and available nitrogen (Av.N ppm) of soil after the coriander plant harvested, were $57.33 \%, 3.17 \mathrm{Cm} / \mathrm{h}$ ), $2.28 \%$ and 128.19 ppm respectively resulted from the treatment [irrigation water regime (15) times, depth from surface soil (10) cm and amount of biogas fertilizer (20) $\left.\mathrm{m}^{3} / \mathrm{Fed}\right]$ compared with all treatments.

Keywords: Coriander, irrigation regime, biogas solid fertilizer, growth parameters.

1- Agricultural Engineering Research Institute, Agriculture Research Centre, Egypt.

2- Soil water and environment Research Institute, Agriculture Research Centre, Egypt. 


\section{INTRODUCTION}

Because of the great importance of coriander (Coriandrum sativumL.) plants in pharmaceutical and food industries, more investigations for improving the growth and productivity of this plant are still needed. It is known that Egypt is a downstream country of the Nile River. Based on this fact, the great challenge for the coming decades will be the task of increasing the productivity of water units (Abdin and Salem, 2009). Irrigation as an environmental factor has an important role in plant growth and is essential to increase yield and quality of plants (Singh and Goswamy, 2000). Deficit irrigation, one of the environmental stresses, is the most significant factor restricting plant growth and crop productivity in the majority of agricultural fields of the world (Abedi and Pakniyat, 2010). Identifying growth stages of a particular cultivar under local conditions of climate and soil fertility allows irrigation scheduling to maximize crop yield and most efficient use of scarce water resources (Mahal and Sidhu, 2006). Nitrogen fertilization and the correct supply of water play an important role in the quality and yield aspects of coriander Angeli et al (2016). Prolonging the irrigation intervals reduced the growth and yield of various medicinal and aromatic plants (Eid et al., 1995; Hammam, 1996). Irrigation of coriander plants at higher levels resulted in the highest vegetative growth characters and yield component compared to the lower levels (Osman, 2000; Osman and El-Feky, 2005). Reducing the irrigation level reduced the seed yield of coriander (Tomar et al., 1994; Kumar et al., 2008). Increase in irrigation water increased dry matter and yield however water soluble carbohydrate was decreased (Islam et al., 2012). Water deficit severely affected all growth parameters and yield attributes with the exception of the number of branches per caraway plant. Moreover, the seed yield and its components significantly decreased under moderate and severe water deficit (Laribi et al., 2009). Kamkar et al. (2011) mentioned that the lower WUE was associated with a higher amount of irrigation water. The volatile oil of various medicinal and aromatic plants was affected as a result of applying different irrigation treatments. Limited water supply is an important factor affecting growth and metabolic activities of plant species. It has a generally negative effect on plant growth and development. However there are reports on the positive effect of limited water supply, as far as the biosynthesis of secondary metabolites, enzyme activities and solute 
accumulation are concerned (Singh- Sangwan et al., 2001). Deficit irrigation can change plant behavior regarding the biosynthesis of primary and secondary metabolites. In addition, drought influences the essential oil biosynthesis (Laribi et al., 2009; Bettaieb et al., 2011; Bourgou et al., 2011) and therefore affects the composition of essential oil. Increasing the irrigation intervals increased the volatile oil percentage; however the volatile oil yield was in an opposite manner (Afify et al., 1993; Eid et al., 1995; Hammam, 1996). On the other hand, the maximum volatile oil yield of coriander was obtained when the lowest irrigation rate was applied compared to the highest irrigation rate (Osman, 2000). Irrigation water also affected not only the volatile oil percentage but also oil composition of coriander fruits (Hassan et al., 2012). The chemical constituents of medicinal and aromatic plant herbs were also affected by irrigation treatments (El-Shafie et al., 1994; Hammam, 1996; Osman, 2000). From the previous literature, it will be beneficial to determine the optimum irrigation level of coriander plants in order to increase the productivity of water unit. Therefore, the aim of this work was to study the effect of irrigation water regime, dry biogas fertilizer rate and fertilization depth on coriander growth parameters and some physical and chemical properties of soil. (Mohamed 2000); on Carum carvi L. plants found that both essential oil percentage and oil yield were increased with decreasing the irrigation intervals. Increasing irrigation level from $70 \%$ (ETP) to $110 \%$ ( ETP) significantly increased the essential oil yield of C. sativum 1. plant. (Halepyati et al., 1996). Prolonging the irrigation intervals reduced the growth and yield of various medicinal and aromatic plants.

\section{MATERIALS AND METHODS}

\subsection{Experimental site}

The experimental work was conducted during November 2016 at Tractors and Farm machinery Testing \& Research Station at Sabahia, Alexandria Governorate, Egypt, to study the effect of dry bio gas fertilizer rate, fertilization depth and irrigation water regime on the coriander growth parameters as well as some physic-chemical properties of soil.

\subsection{Soil description}

Soil samples were collected and analyzed to determine some physical and chemical characteristics of the investigated soil according to the standard methods outlined by black et. al. (1965), Jackson (1967) and page et al. 
(1982). Total nitrogen $(\mathrm{T}-\mathrm{N})$ and available $(\mathrm{Av}-\mathrm{N})$ were extracted and determined according to the methods under taken by Soltanpour and Schwab (1977) and Jackson (1973). Data were represented in Table 1. Table (1). some physical and chemical properties of the tested soil.

\begin{tabular}{|l|c|}
\hline \multicolumn{2}{|c|}{ Properties } \\
\hline \multicolumn{2}{|c|}{ Chemical properties } \\
\hline PH (1:2.5) soil : water & 7.95 \\
\hline EC,d S m-1 (1:2.5) & 2.60 \\
\hline Soluble Cations (meq/L) & 4.80 \\
1. Na & 0.10 \\
2. $\mathrm{K}^{+}$ & 11.5 \\
3. $\mathrm{Ca}^{+}$2 & 5.66 \\
4. $\mathrm{Mg}^{+}$2 & 7.00 \\
Soluble anions (meg/L) & 5.50 \\
1. $\mathrm{HCO}_{3}$ & 9.66 \\
2. $\mathrm{CL}^{+}$ & 0.10 \\
3. SO ${ }_{4}$ & 24.24 \\
\hline Total nitrogen, \% (T.N) & 4.85 \\
\hline Available nitrogen ,ppm (Av.N) & 9.55 \\
\hline Total Carbonat \% (CaCo $\left.{ }_{3}\right)$ & 51.25 \\
\hline Cation exhangable capacity (CEC) meg/100 soil & 01.75 \\
\hline \multicolumn{2}{|c|}{ Physical properties } \\
\hline Total porosity, (T.P) \% & 17.95 \\
\hline Hydraulic Conductively (HC) (cm/h) & Sand clay loam \\
\hline Available water, (Av.W) \% & 44.20 \\
\hline Texture class & 26.10 \\
\hline Particle size distribution, \% & 29.76 \\
\hline 1- Sand & 1.31 \\
2- Silt & \\
3- Clay & \\
\hline Soil bulk density (gm/cm ${ }^{3}$ ) & \\
\hline
\end{tabular}

\section{Chemical analysis of water}

The chemical analysis of water was carried out at Analyzed in Saline and Alkaline research Lab Alexandria, which were 0.9, 0.25, 0.00, 0.3, 0.8,15 and 8 (meq/L) for $\mathrm{Ca}, \mathrm{Mg}, \mathrm{CO} 3, \mathrm{HCO} 3, \mathrm{CL}, \mathrm{Na}$ and $\mathrm{K}$, respectively.

\subsection{Planting treatments and experimental design}

The experiment was performed in split split- plot system in a randomized complete block design (RCBD) with three replicates. Treatments consisted of two amounts of biogas fertilizer 15 and $20 \mathrm{~m}^{3} / \mathrm{fed}$, three fertilization depths of 5, 10 and $15 \mathrm{~cm}$ from the surface of the earth, and 
three irrigation water regimes as three periods of irrigation 7-10-15 times at the season as well as the control.

Coriander seeds were sown in the soil in row $10.0 \mathrm{~m}$ length and $0.6 \mathrm{~m}$ apart, the spacing between plants $0.25 \mathrm{~m}$. Seeds were sown in holes at space of $25 \mathrm{~cm}$ in between, about 3-4 seeds were sown in every hole. Thinning process to one plant per hole was performed 40 days after sowing. The total area of the experiment was about $360 \mathrm{~m} 2$, divided into 72 plots; each plot area was $(3 \mathrm{~m} \times 1 \mathrm{~m})$. There were 12 plants in every row, 36 plants in each plot. Plants were irrigated by flooding irrigation up to the field capacity $\left(1200 \mathrm{~m}^{3} / \mathrm{fed}\right)$. The plants were harvested and its growth parameters data were recorded: plant height, number of main branches per plant, number of umbels per plant, diameter of umber per plant and yield.

\subsection{Dry biogas manure application:}

The dry biogas manure brought from the biogas project located at Tractors and Farm machinery Testing \& Research Station, Sabahia, Alexandria Governorate, Egypt. The components of the dry biogas manure were analyzed in the laboratories of the services unit of soil analysis, Soil Department, Faculty of Agriculture, Alexandria University, Egypt. Table (2) shows characteristics of the investigated dry biogas manure. The dry fertilizer was added to each treatment by scaling the surface of soil at depths of 5,10 and $15 \mathrm{~cm}$ respectively then adding the dry biogas fertilizer and then creating the lines.

Table (2): Characteristics of dry biogas fertilizer.

\begin{tabular}{|l|l|}
\hline \multicolumn{1}{|c|}{ Item } & \multicolumn{1}{c|}{ Value } \\
\hline Bulk density & $450 \mathrm{~kg} / \mathrm{m}^{3}$ \\
\hline Moisture content & $7-10 \%$ \\
\hline Nitrogen content & $22 \mathrm{~kg} / \mathrm{ton}$ \\
\hline Phosphorus content & $27 \mathrm{~kg} / \mathrm{ton}$ \\
\hline Potassium content & $61.5 \mathrm{~kg} / \mathrm{ton}$ \\
\hline Organic matter & $50 \%$ \\
\hline
\end{tabular}

\section{RESULTS AND DESCUSSION}

Effect of dry biogas fertilizer, fertilization depth and irrigation water regime on the growth parameters of coriander:

Table 3 shows the effect of dry biogas fertilizer rate 15 and $20\left(\mathrm{~m}^{3} / \mathrm{fed}\right)$, three fertilization depth of surface soil 5, 10 and $15(\mathrm{~cm})$ and three levels of irrigation 7, 10 and 15 (irrigations times) on the coriander growth parameters. 
Table (3): Effect of irrigation water regime, dry biogas fertilizer rate and fertilization depth on the coriander growth parameters.

\begin{tabular}{|c|c|c|c|c|c|c|c|}
\hline $\begin{array}{c}\text { biogas } \\
\text { fertilizer rate, } \\
\mathbf{m}^{\mathbf{3} / \mathbf{f e d}} \\
\end{array}$ & $\begin{array}{c}\text { Depth } \\
\text {,cm }\end{array}$ & $\begin{array}{c}\text { Irrigation } \\
\text { regime }\end{array}$ & $\begin{array}{l}\text { yield, } \\
\text { kg/fed }\end{array}$ & $\begin{array}{l}\text { Branc } \\
\text { h. No. }\end{array}$ & $\begin{array}{c}\text { Plant } \\
\text { Height } \\
, \mathrm{cm}\end{array}$ & $\begin{array}{c}\text { Flower } \\
\text { Diam. } \\
\text { cm }\end{array}$ & $\begin{array}{l}\text { No. of } \\
\text { fruits }\end{array}$ \\
\hline \multirow{9}{*}{15} & \multirow{3}{*}{5} & 7 & 933.6 & 5.18 & 63.78 & 3.43 & 61.3 \\
\hline & & 10 & 1019.2 & 5.37 & 65.83 & 3.62 & 66 \\
\hline & & 15 & 1041.4 & 5.66 & 66.77 & 3.87 & 66.9 \\
\hline & \multirow{3}{*}{10} & 7 & 1104 & 5.21 & 68.76 & 3.03 & 69.1 \\
\hline & & 10 & 1171.2 & 6 & 71.8 & 3.7 & 78.5 \\
\hline & & 15 & 1208 & 6.6 & 90.03 & 4.3 & 80.3 \\
\hline & \multirow{3}{*}{15} & 7 & 1000 & 5.31 & 68.22 & 2.98 & 62.29 \\
\hline & & 10 & 1038.4 & 5.66 & 71.12 & 3.13 & 63.71 \\
\hline & & 15 & 1052.8 & 5.88 & 75.8 & 3.79 & 66.11 \\
\hline \multirow{9}{*}{20} & \multirow{3}{*}{5} & 7 & 955.2 & 5 & 76.95 & 2.75 & 61.19 \\
\hline & & 10 & 980.8 & 5.23 & 71.61 & 3.09 & 63.33 \\
\hline & & 15 & 1004.8 & 5.79 & 74.35 & 3.31 & 64.1 \\
\hline & \multirow{3}{*}{10} & 7 & 1132 & 5.21 & 64.46 & 3.19 & 67.2 \\
\hline & & 10 & 1169.6 & 5.33 & 66.39 & 3.45 & 71.4 \\
\hline & & 15 & 1120.8 & 6.33 & 87.5 & 3.77 & 73.7 \\
\hline & \multirow{3}{*}{15} & 7 & 960.9 & 5.21 & 70.09 & 2.89 & 61.12 \\
\hline & & 10 & 974.4 & 5.49 & 71.65 & 3.41 & 64.47 \\
\hline & & 15 & 1000 & 5.73 & 83.91 & 3.79 & 65.97 \\
\hline \multicolumn{2}{|c|}{ Control } & 15 & 665.6 & 4.37 & 60 & 2.93 & 54.67 \\
\hline \multicolumn{3}{|c|}{ Means } & 1033.2 & 5.48 & 74.10 & 3.29 & 65.83 \\
\hline \multicolumn{3}{|c|}{ L.S.D. of Fertilizer rate } & 30.5 & 0.16 & 2.99 & 0.24 & 2.51 \\
\hline \multicolumn{3}{|c|}{ L.S.D. of fertilization Depth } & 26.42 & 0.14 & 2.59 & 0.21 & 2.17 \\
\hline \multicolumn{3}{|c|}{ L.S.D. of irrigation } & 20.57 & 0.12 & 2.11 & $\mathbf{0 . 1 7}$ & 1.77 \\
\hline
\end{tabular}

Generally, the experimental results showed that the three levels of water regime and the applied fertilization rates of solid biogas fertilizer as well as the fertilizer depth had a significant effect on all growth characteristics of the coriander plant compared with the control treatment. It was noticed that the high significant differences were resulted from the treatment [amount of biogas fertilizer $(\mathbf{1 5}) \mathrm{m}^{3} / \mathrm{Fed}+$ depth from surface soil (10) $\mathrm{cm}+$ level of irrigation (15) times], the maximum mean value of yield, plant height, number of branches, number of umbels and umbels diameter, were $1208 \mathrm{~kg} / \mathrm{fed}, 90.03 \mathrm{~cm}, 6.60,80.30$ and $4.2 \mathrm{~cm}$ respectively compared to the control treatment. These results assure with those of Mahal and Sidhu (2006), Eid et al. (1995), Hammam, (1996). and Angeli et al (2016). The improvement rate in the growth parameters of 
coriander crop was (40.3 to 80.5$) \%$ in the yield, (6.3 to 50.0$) \%$ in plant height, (14.4 to 50)\% in number of branches, (11.8 to 46.9$) \%$ in number of umbels and up to $46.8 \%$ in umbel diameter; which confirms that the dry biogas fertilizer, irrigation water regime and the fertilization depth have a high positive effect.

Effect of irrigation water regime, dry biogas fertilizer rate and fertilization depth on some physical and chemical properties of soil:

Table (4) showed the effect of dry biogas fertilizer rate, fertilization depth and irrigation water regime on total porosity, (T.P \%), hydraulic conductivity $(\mathrm{Kb} \mathrm{Cm} / \mathrm{h})$, total nitrogen (T.N \%) and available nitrogen (Av.N ppm) of tested soil planted of coriander plant.

Table (4) Effect of irrigation water regime, dry biogas fertilizer rate and fertilization depth on T-P \%, Kb $\mathrm{Cm} / \mathrm{h}$, T.N\%, Av.N ppm of soil after harvesting coriander plant.

\begin{tabular}{|c|c|c|c|c|c|c|}
\hline \multicolumn{3}{|c|}{ TREATMENTS } & \multirow[t]{2}{*}{ T.P \% } & \multirow{2}{*}{$\begin{array}{l}\text { K.b } \\
\mathbf{C m} / \mathbf{h}\end{array}$} & \multirow[t]{2}{*}{ T.N \% } & \multirow{2}{*}{$\begin{array}{l}\text { Av.N } \\
\text { ppm }\end{array}$} \\
\hline $\mathrm{m}^{3} /$ fed & Depth (cm) & Times & & & & \\
\hline \multicolumn{2}{|c|}{ CONTROL } & 15 & 50.05 & 1.74 & 0.107 & 72.75 \\
\hline \multirow{9}{*}{15} & \multirow{3}{*}{5} & 7 & 55.21 & 2.6 & 1.98 & 121.50 \\
\hline & & 10 & 55.36 & 2.69 & 1.98 & 120.41 \\
\hline & & 15 & 55.58 & 2.64 & 1.96 & 121.29 \\
\hline & \multirow{3}{*}{10} & 7 & 56.23 & 2.67 & 2.07 & 119.20 \\
\hline & & 10 & 56.48 & 2.74 & 2.09 & 120.95 \\
\hline & & 15 & 57.2 & 3.01 & 2.25 & 127.92 \\
\hline & \multirow{3}{*}{15} & 7 & 55.92 & 2.76 & 1.99 & 120.80 \\
\hline & & 10 & 56.07 & 2.75 & 2.01 & 122.58 \\
\hline & & 15 & 56.52 & 2.77 & 2.02 & 122.77 \\
\hline \multirow{9}{*}{$\mathrm{S}_{2}$} & \multirow{3}{*}{5} & 7 & 55.93 & 2.7 & 2.03 & 123.10 \\
\hline & & 10 & 56.09 & 2.72 & 2.06 & 121.90 \\
\hline & & 15 & 56.18 & 2.74 & 2.09 & 119.50 \\
\hline & \multirow{3}{*}{10} & 7 & 56.26 & 2.72 & 2.08 & 125.40 \\
\hline & & 10 & 56.33 & 2.75 & 2.10 & 124.22 \\
\hline & & 15 & 57.33 & 3.17 & 2.28 & 128.19 \\
\hline & \multirow{3}{*}{15} & 7 & 56.4 & 2.8 & 2.13 & 120.15 \\
\hline & & 10 & 56.58 & 2.78 & 2.20 & 126.98 \\
\hline & & 15 & 56.68 & 2.89 & 2.21 & 126.82 \\
\hline & L.S.D at 0.05 & & 1.81 & 0.21 & 0.19 & 8.92 \\
\hline
\end{tabular}

The results showed significance differences due to the effect of all treatments comparing with the control treatment. The maximum significant difference resulted from the treatment (15) times, (10) cm and 
(20) $\mathrm{m}^{3} /$ fed, where the average values of total porosity, (T.P\%), hydraulic conductivity ( $\mathrm{Kb} \mathrm{Cm} / \mathrm{h})$, total nitrogen (T.N\%) and available nitrogen (Av.N ppm) were $57.33 \%, 3.17 \mathrm{Cm} / \mathrm{h}$ ), 2.28\% and $128.19 \mathrm{ppm}$ respectively.

\section{CONCULATIONS}

1-The evaluated growth parameters (yield, plant height, number of bunches, number of umbels and umbel diameters) were influenced by irrigation water regime, dry biogas fertilizer rate and fertilization depth.

2- The treatment irrigation water regime (15) times, fertilization depth from surface soil (10) $\mathrm{cm}$ and dry biogas fertilizer rate (15) $\mathrm{m}^{3} /$ fed caused the highest average yield (1208 kg/fed).

3- The maximum average plant height $(90 \mathrm{~cm})$ was obtained at irrigation water regime (15) times, fertilization depth from surface soil (10) $\mathrm{cm}$ and dry biogas fertilizer rate (15) $\mathrm{m}^{3} /$ fed.

4- The maximum average number of branches (6.6) and maximum average number of fruits (80.3) were obtained at irrigation water regime (15) times, fertilization depth from surface soil (10) $\mathrm{cm}$ and dry biogas fertilizer rate $(15) \mathrm{m}^{3} /$ fed.

5- The most important parameter for the farmer is the yield; thus the irrigation water regime (15) times, fertilization depth from surface soil (10) $\mathrm{cm}$ and dry biogas fertilizer rate (15) $\mathrm{m}^{3} /$ fed are the recommended for higher coriander yield.

6- Generally, the physical and chemical properties of soil after coriander plant harvesting showed greater improvements comparing with control treatment in total porosity, (T.P\%), $(\mathrm{Kb} \mathrm{Cm} / \mathrm{h})$, total nitrogen (T.N\%) and available nitrogen (Av.N ppm) the maximum average improvements values were $66.99 \%, 2.99 \mathrm{Cm} / \mathrm{h}, 1.98 \%$ and $126.88 \mathrm{ppm}$ respectively caused by the treatment irrigation water regime (15) times, fertilization depth from surface soil (10) $\mathrm{cm}$ and dry biogas fertilizer rate $(15) \mathrm{m}^{3} / \mathrm{fed}$ compared the control treatment. 


\section{REFERENCES}

Abedi, T., and H., Pakniyat, (2010). Antioxidant enzyme changes in response to drought stress in ten cultivars of oilseed rape (Brassicanapus L.). Czech J. Genet. Plant Breed 46 (1), 27-34.

Abdin,.A.E and S,. Salem, (2009).Strategic plants for sugar cane cultivation in upper Egypt towards the implementation of rational water use Egypt .J. Agric Econ, 19(1),308 333.

Afify, M.M., M.M., Mazrou,and M.A., Eraki, (1993). The growth and essential oil content of Salvia officiualis L. plants as affected by watering intervals, nitrogen fertilization and their combination. Zagazig. J. Agric. Res. 20 (6), 1913-1924.

Angeli K. P., F. T., Delazari, C., Nick G. M. Ferreria and D. J. H., Da Silva (2016). Yield components and water use efficiency in coriander under irrigation and nitrogen fertilization. Rivista Brasileira de Engenharia Agricola e Ambiental. V. 20, n. 5, P. 415420, 2016 .

Black, C.A.(Ed.) (1965). Methods of soil Analysis .Part 1l.Agron.ASA and SSSA,Madison,Wl.

Bettaieb, I., S., Knioua, I., Hamrouni, F., Limam, and B., Marzouk, (2011). Water-deficit impact on fatty acid and essential oil composition

Bourgou, S., I., Bettaieb, M., Saidani, and B., Marzouk, (2011). Fatty acids, essential oil, and phenolics modifications of black cumin fruit under $\mathrm{NaCl}$ stress conditions. J. Agric. Food Chem. 59, 328-334.

Eid, Malaka I., Ahmed, K.,Shadia and K.K.,Mortada, (1995). The influence of irrigation intervals and phosphorus fertilization on growth seed and oil yield of anise plant (Pimpinella anisum, L.). Egypt. J. Agric. Res 74 (3), 733-742.

El-Shafie, S.M., M.M., Mazron, M.A., Eraki and S.A., Saffan, (1994). Physiological studies on Roselle (Hibiscus sabdariffa L.) plants(A) effect of watering intervals, nitrogen fertilization levels and their 
combination on the growth yield and the uptake of some nutrient elements. Zagazig. J. Agric Rec. 21 (1), 209-226.

Halepyati, A.S., K.,Sujatha, and M.M., Prabhakar, (1996). Growth, yield, water relations and its use in tuberose (Polianthes tuberosa) asinfluenced by irrigation regime and nitrogen level. Indian J. Agric. Sci. 65 (12), 866-869.

Hammam, A.K. (1996). Effect of nitrogenous fertilization and irrigation on growth, yield and active constituents of Anis plants (Pimpninella anisum). M.Sc. Thesis, Fac. Agric. Cairo Univ. Egypt.

Hassan, F.A.S., E.F., Ali, and S.A., Mahfouz, (2012). Comparison between different fertilization sources, irrigation frequency and their combinations on the growth and yield of coriander plant Aus .J. Basic Appl. Sci. 6(3), 600-615.

Islam, M.R., S.C.,Garcia, and A., Horadagoda, (2012). Effects of irrigation and rates and timing of nitrogen fertilizer on dry matter yield, proportions of plant fractions of maize and nutritive value and in vitro gas production characteristics of whole crop maize silage. Animal Feed Sci. Technol. 172, 125-135.

Jackson, M.L.(1967). Soil chemical Analytic . Constable Co, Ltd . Lodon Oxoid Manual of Culture Midia, Ingredients and other laboratory. Services 1965. oxoid limited, London.

Jackson, M.L.(1973) Soil chemical analysis prentice-hall of sndian private limited. New Delhi.

Kamkar, B., A.R.,Daneshmandb, F.,Ghooshchic, A.H Shiraniradd, and A.R.,Safahani, (2011). The effects of irrigation regimes and nitrogen rates on some agronomic traits of canola under a semiarid environment. Agric. Water Manage. 98, 1005-1012.

Kumar, A., R.,Singh, and R.K.,Chhillar, (2008). Influence of omitting irrigation and nitrogen levels on growth, yield and water use efficiency of coriander (Coriandrum sativum L.). Acta Agronomica Hungarica 56 (1), 69-74. 
Laribi, B., I.,Bettaieb, K.,Kouki, A.,Sahli, A.,Mougou, and B.,Marzouk, (2009). Water deficit effects on caraway (Carum carvi L.) growth, essential oil and fatty acid composition. Ind. Crop Prod. 31, 34-42.

Mahal, S.S., and A.S.,Sidhu, (2006). Effect of different irrigation schedulesand nitrogen levels on growth yield attributes and seed yield ofhybrid canola (Brassica napus L.). Environ. Ecol. 24S (4), $1108-1111$.

Mohamed, I.M. (2000). Studies on the physiological studies in (Coriandrum sativum L. and Carum carvil plants). M.Sc. Thesis, Fac. Agric. Cairo Univ., Egypt.

Osman, A.M., and Y.S.,El-Fiky, (2005). Effect of applied irigaiton water amounts and plant densities on coriander (Coriandrum sativum, L.) production in sandy soils. Annu Conf Misr Soc. Agric. Eng. 22 (4), 758-770.

Osman, A.Y. (2000). Possibility of production of Coriander under Sinaiconditions. M.Sc. Thesis, Fac. Agric. Cairo Univ., Egypt.

Page, A.L., R.H.Miller and R. Kenney (1982).Methods of soil analsis part 2. Book series No. 9. Am.soc. of Agron, and soil sci.soc. Am. Madison, Wisconsin, USA.

Singh, K.K., and T.K.,Goswami, (2000). Thermal properties of cumin seed. J. Food Eng. 45 (4), 181-187

Singh-Sangwan, N., A.H.A.,Farooqi, F.,Shabih, and R.S Sangwan, (2001). Regulation of essential oil production in plants. PlantGrowth Regul. 34, 3-21.

Sultanpour, P. N. and A. B. Schwab, (1977). A new soil test for simultaneous extraction of macronutrients in alkaline soil. Comm. Soil Sci. and plant Annual, 8, 195.

Tomar, K.P., M.A.,Gupta, and K.B.,Nigam, (1994). Effect of irrigationand fertility levels on growth and yield of coriander (Coriandrum stivum). Indian J. Agron. 39 (3), 442-447. 


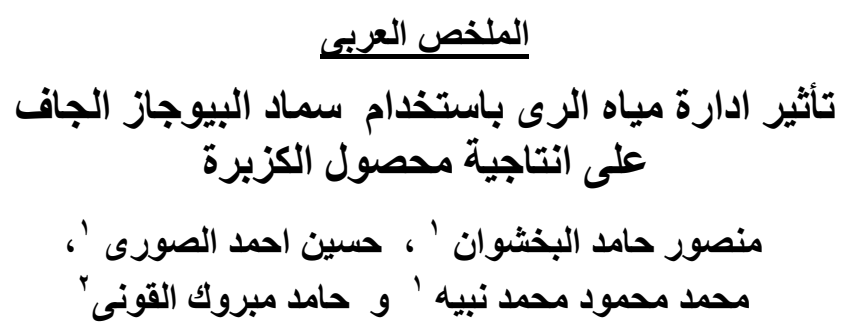

أجريت تجربة حقلية فى نوفمبر IV V P بمحطة ابحاث و اختبار ات الجرار ات والالات الزر اعيةمعهد بحوث الهندسة الزراعية ـ مركز البحوث الزر اعية ـ الاسكندرية بهدف درفية دراسة تأثير اضافة سماد البيوجاز الجاف ( و هو سماد يتم الحصول عليه من تجفيف ناتج تخمر المخلفات

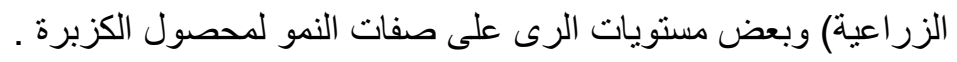

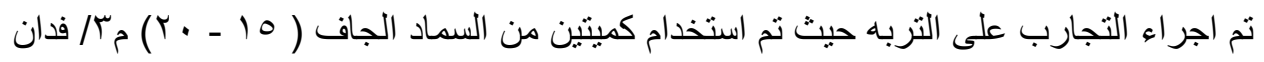
وثلاثه اعماق لوضع السماد (

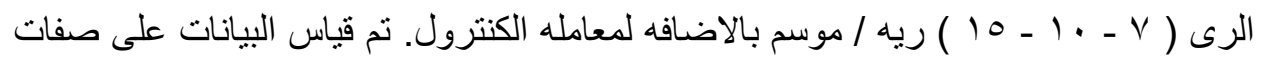

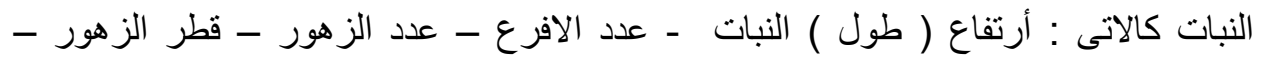

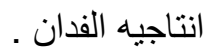

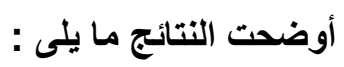
ا ـ كل المعاملات كان لها تأثير معنوى على صفات نمو الكزبره من حيث الانتاجيـة و ارتفاع

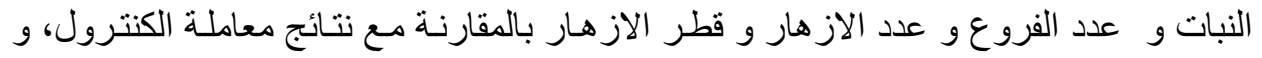

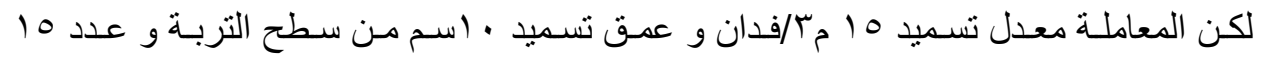
رية/موسم كانت هى الاكثر معنوية مقارنة بكل ملت المعاملات.

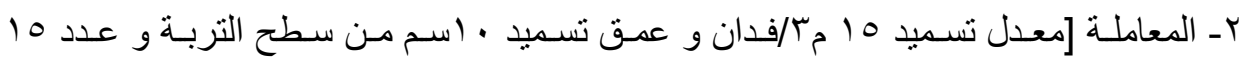

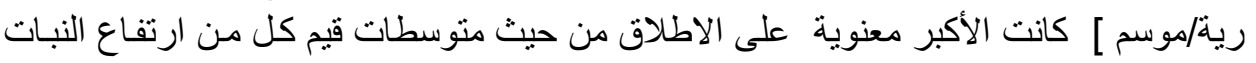

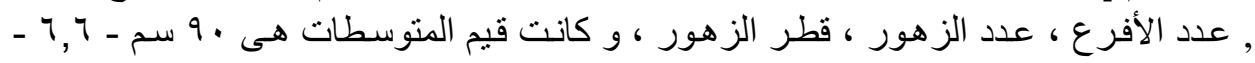
$\varepsilon, r-\Lambda \cdot r$

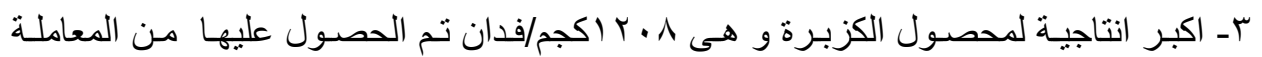

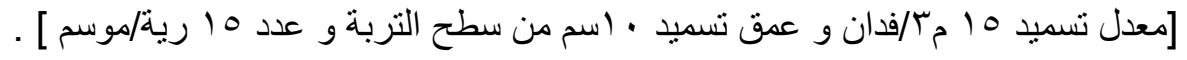
ع - اظهرت كل المعاملات تحسين فى بعض الخواص الفيزيائيسة و الكيميائيسة للتربـة بعد حصساد

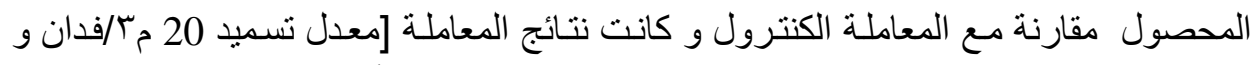
عمق تسميد · (سم من سطح التربة و عدد 10 رية/موسم] هـ الأكبر معنويسة لمتوسطات قيم

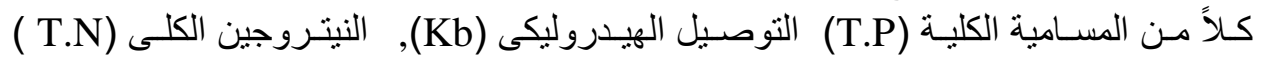
والنيتروجين المناح (Av.N ppm) . 